\title{
Natural Product-Based Drug Discovery - Epothilones as Lead Structures for the Discovery of New Anticancer Agents
}

\author{
Karl-Heinz Altmann, Andreas Flörsheimerª, Guido Bold ${ }^{\mathrm{a}}$, Giorgio Caravattia, \\ and Markus Wartmann ${ }^{\mathrm{a}}$
}

\begin{abstract}
Epothilones are microtubule depolymerization inhibitors, which inhibit the growth of a broad range of human cancer cell lines in vitro with low $\mathrm{nM}$ or sub-nM $\mathrm{IC}_{50} \mathrm{~s}$. Unlike other cytotoxic anticancer agents, epothilones are also active in vitro against multidrug-resistant cell lines and they inhibit the growth of multidrug-resistant tumors in vivo. In order to further our understanding of the structural requirements for biological activity and, ultimately, to identify new microtubule-stabilizing agents with improved overall properties, we have investigated the biological activity of a variety of structurally modified epothilone analogs. This report will focus on two selected aspects of our SAR work, namely (1) the synthesis and biological characterization of a series of 12-aza epothilones and (2) analogs with a conformationally constrained side-chain. Several of these structures exhibit potent in vitro antiproliferative activity, and thus may be interesting candidates for further profiling in tumor models and perhaps for the development of improved clinical candidates.
\end{abstract}

Keywords: Antiproliferative activity · Antitumor activity · Epothilones · Natural products ·

Structure-activity relationships

\section{Introduction and Background}

Cancer represents one of the most severe health problems worldwide and the development of new anticancer drugs and more effective treatment strategies are fields of utmost importance in drug discovery and clinical therapy. While much of this research is currently focused on cancer-specific mechanisms and the corresponding molecular targets (e.g. kinases related to cell cycle progression or signal transduction) [1], the search for improved cytotoxic

${ }^{*}$ Correspondence: Prof. Dr. K.-H. Altmann Swiss Federal Institute of Technology (ETH) Zürich Institute of Pharmaceutical Sciences

ETH Hönggerberg, $\mathrm{HCl} \mathrm{H} 405$

$\mathrm{CH}-8093$ Zürich

Tel.: +41446337390

Fax: +41446331360

E-Mail: karl-heinz.altmann@pharma.ethz.ch

aNovartis Institutes for Biomedical Research Basel DA Oncology

$\mathrm{CH}-4002$ Base agents (acting on ubiquitous targets such as DNA or tubulin) still represents an important aspect of modern anticancer drug discovery. As the major types of solid human tumors (breast, lung, prostate, and colon), which constitute the vast majority of cancer cases today, are multi-causal in nature, there is a growing recognition that the treatment of solid tumors with 'mechanismbased' agents alone is unlikely to be successful in a general sense. Instead, improved treatment strategies are likely to involve combinations of e.g. signal transduction inhibitors with new and better cytotoxic drugs.

Microtubule inhibitors constitute an important group of cytotoxic anticancer drugs [2], with clinical applications in the treatment of a variety of cancer types, either as single agents or as part of different combination regimens [3]. Microtubule-interacting agents can be subdivided into two mechanistically distinct classes, namely compounds which inhibit the assembly of tubulin heterodimers into microtubule polymers ('tubulin polymerization inhibitors') and those which stabilize microtubules under normally destabilizing conditions ('microtubule stabilizers') [4]. The latter will also promote the assembly of tubulin heterodimers into microtubule polymers. While tubulin polymerization inhibitors such as vincristine and vinblastine were introduced into clinical cancer therapy already forty years ago, microtubule-stabilizing agents have only been in clinical use for little more than a decade. The first agent of this type to obtain FDA approval was paclitaxel $\left(\right.$ Taxol $\left.^{\circledR}\right)$ in 1992, which was followed by its closely related analog docetaxel (Taxotere ${ }^{\circledR}$ ) in 1996 and the emergence of microtubule-stabilizing anticancer drugs clearly marks a significant advance in cancer chemotherapy [5].

Historically more than a decade passed after the elucidation of paclitaxel's mode of action in 1979 [6] before alternative microtubule-stabilizing agents were discovered, bearing no structural resemblance to paclitaxel or other taxanes. Most prominent among these new microtubule stabilizers is a group of bacteria-derived macrolides, which were discovered in 1993 by Reichenbach and Höfle and have been termed 'epothilones' by their discoverers (Fig. 1) [7].

Although not immediately recognized, these compounds were subsequently 

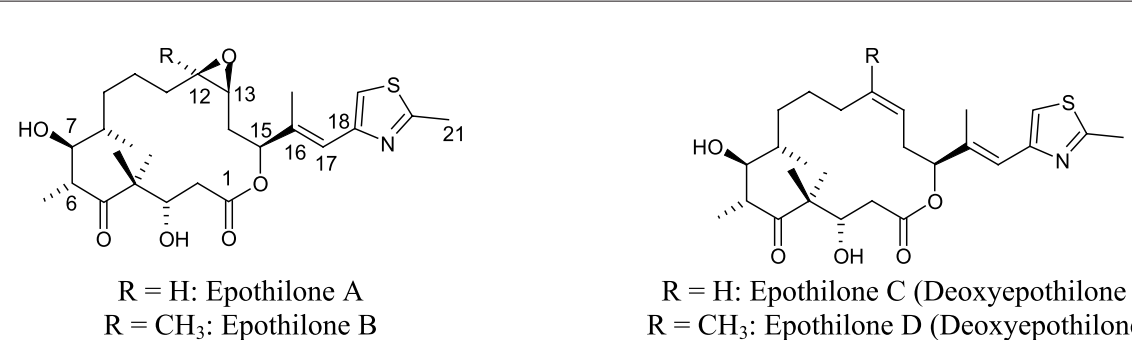

$\mathrm{R}=\mathrm{H}$ : Epothilone C (Deoxyepothilone A) $\mathrm{R}=\mathrm{CH}_{3}$ : Epothilone D (Deoxyepothilone B)

Fig. 1. Structures of epothilones A-D

Table 1. Induction of tubulin polymerization and growth inhibition of human carcinoma cell lines by epothilones A-D and paclitaxel.

\section{\%Tubulin Polymerization ${ }^{\text {a, c }}$}

Epo A

Epo B

Epo C

Epo D

Paclitaxel

$\mathrm{IC}_{50} \mathrm{~KB}-31$
$[\mathrm{nM}]^{\mathrm{b}, \mathrm{c}}$

$\mathrm{IC}_{50} \mathrm{~KB}-8511$ $[\mathrm{nM}]^{\mathrm{b}, \mathrm{c}}$

$\begin{array}{cc}2.10 & 1.89 \\ 0.19 & 0.19 \\ 25 & 64 \\ 2.70 & 1.44 \\ 2.31 & 531\end{array}$

anduction of polymerization of porcine brain microtubule protein by $2 \mu \mathrm{M}$ of test compound relative to the effect of $25 \mu \mathrm{M}$ of Epo $\mathrm{B}$, which gave maximal polymerization (85\% of protein input). b $_{50}$-values for growth inhibition of human epidermoid carcinoma cell lines KB-31 and KB-8511. KB-8511 is a P-gp-overexpressing multidrug-resistant subline of the KB-31 parental line. Values represent means of at least three independent experiments. 'Data from [14]. demonstrated by a group at Merck Research Laboratories to possess a paclitaxellike mechanism of action [8]. Apart from epothilones a growing number of additional natural products have been recognized over the last few years to be microtubule stabilizers, thus providing a whole new set of diverse lead structures for anticancer drug discovery (for a recent review [9]). It is interesting to note in this context that a number of small synthetic molecules are known which act as efficient tubulin polymerization inhibitors [10], but that all potent microtubule-stabilizing agents identified to date are natural products or natural product-derived [9].

Due to suppression of microtubule dynamics [11], low $\mathrm{nM}$ concentrations of epothilones cause aberrant mitotic spindle formation [8][12], resulting in cell cycle arrest in mitosis and subsequent apoptotic cell death. As a consequence Epo A and B inhibit the proliferation of a broad range of human cancer cell lines in vitro with $\mathrm{nM}$ (Epo A) or even sub-nM (Epo B) $\mathrm{IC}_{50} \mathrm{~s}$ (Table 1).

In contrast to paclitaxel, epothilones are potent growth inhibitors of drug-sensitive as well as multidrug-resistant cancer cell lines (Table 1) [8][12][13] and they have been shown to be active in vitro against cell lines whose paclitaxel-resistance is derived from specific tubulin mutations [12][15]. In addition, Epo B and a number of its analogs have been demonstrated to possess potent in vivo antitumor activity (reviewed $e . g$. in [16-18]) and at least five compounds of this class are currently undergoing clinical evaluation in humans. These include Epo B itself (Novartis), Epo D (Kos-862; SloanKettering Cancer Center/Kosan), BMS247550 (the lactam analog of Epo B; Bristol-Myers-Squibb), BMS-310705 (C21-amino-Epo B; Bristol-Myers-Squibb) and ABJ879 (C20-desmethyl-C20-methylsulfanyl-Epo B; Novartis) [17][18].

Unlike the situation with paclitaxel, where a practical synthesis clearly was (and still is) out of reach, numerous total syntheses of epothilones have been published in the literature since the first disclosure of their absolute stereochemistry in 1996 [19] (reviewed in [20-23]). At the same time, and perhaps more importantly, the methodology developed for the synthesis of the natural products has provided the basis for the generation of a host of synthetic analogs on a scale sufficient for extensive in vitro profiling and SAR studies (reviewed in [13][14][16-18][20-23]). In addition, even the large-scale production of such compounds for clinical studies is likely to be feasible [21][24].
This account will focus on some selected aspects of our own synthetic work on epothilone analogs and the associated SAR studies. Apart from trying to contribute to a better general understanding of the structural requirements for biological activity, the ultimate goal of this research is the identification of improved microtubule-stabilizing agents. Within this context, one particular objective of our work was (and still is) the discovery of alternative structural scaffolds with potent antiproliferative activity through extensive alteration (and simultaneous simplification) of the natural epothilone template.

\section{Synthesis of Epothilone Analogs and SAR Studies}

\subsection{2-Aza-Epothilones}

Our early SAR work on modified epothilones was guided by the potent biological activity associated with the deoxyepothilone structural framework (Fig. 1), which had been established through the work of Danishefsky and Nicolaou [25-28]. Thus, Epo C and D are virtually equipotent inducers of tubulin polymerization in vitro as the corresponding parent epoxides and their antiproliferative activity is within a 5-30-fold range of that of Epo A and $\mathrm{B}$, respectively. Based on this observation we hypothesized that epothilone analogs incorporating C(12)-N(13)-alkyl amide groups (1; Scheme 1), would exhibit potencies comparable to that of Epo D due to similar conformations of the macrocycle in both cases (assuming a preference of the C-N partial double bond for a cis conformation). At the same time these polar double-bond substitutes were expected to result in improved aqueous solubility over the very lipophilic Epo D.

As schematically illustrated in Scheme 1 , the key intermediate in the synthesis of these amide-based analogs as well as many other types of analogs investigated in our laboratory is the $\mathrm{C}(1)-\mathrm{C}(11)$ fragment 5 [29]. As exemplified in Scheme 2 for methyl amide-based analog $\mathbf{1 a}, \mathbf{5}$ could be readily elaborated into target structures $\mathbf{1}$ through functional group transformation, amide coupling and macrolactonization (Scheme 2).

Unfortunately, compound 1a and related analogs were found to lack any tubulin polymerizing or antiproliferative activity $\left(\mathrm{IC}_{50}\right.$ values for growth inhibition were between 5 and $10 \mu \mathrm{M}$ ) [30], in spite of the fact that NMR studies with 1a in DMSO/water mixtures indicated that the preferred conformation about the 12/13 N-methyl amide bond is indeed cis, i.e. with the methyl group and the carbonyl oxygen on the same side of the partial $\mathrm{C}-\mathrm{N}$ double bond (cis/trans ratio $\sim 4: 1)$ ). The underlying rea- 


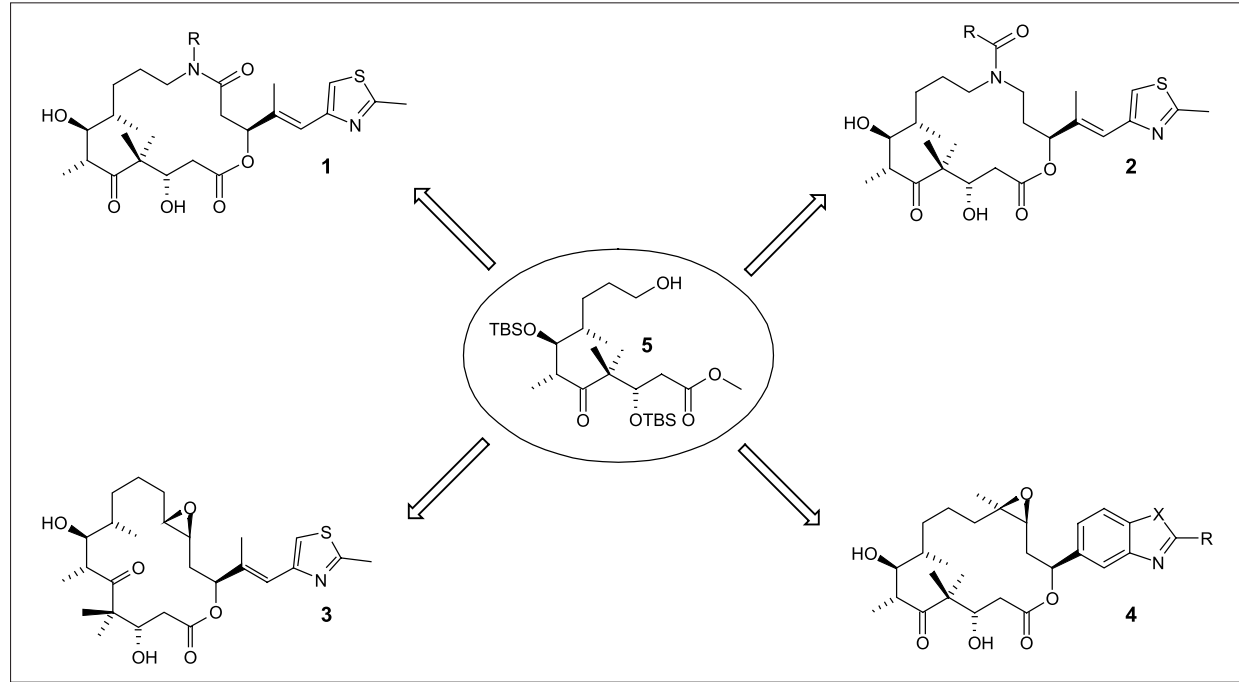

Scheme 1. Target structures accessible through intermediate 5. (trans-Epothilone A 3 is not discussed in this paper [29]).

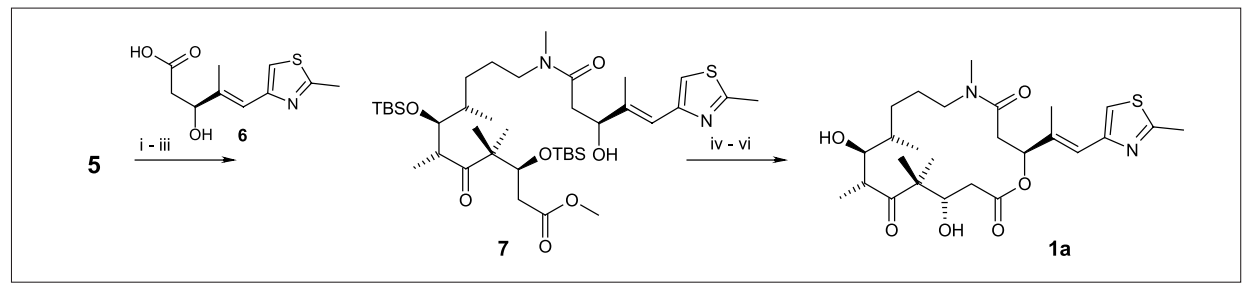

Scheme 2. i. Mes- $\mathrm{Cl}, \mathrm{Et}_{3} \mathrm{~N}, \mathrm{CH}_{2} \mathrm{Cl}_{2}, 0^{\circ} \mathrm{C}, 1 \mathrm{~h}, 91 \%$. ii. $\mathrm{CH}_{3} \mathrm{NH}_{2}, \mathrm{MeOH}, 50{ }^{\circ} \mathrm{C}, 4$ h. iii. 6, DCC, $\mathrm{HOBt}$, DIEA, DMF, $28 \%$ (2 steps). iv. $\mathrm{NaOH}, \mathrm{MeOH} / \mathrm{H}_{2} \mathrm{O}, 58 \%$. v. 2,4,6- $\mathrm{Cl}_{3} \mathrm{C}_{6} \mathrm{H}_{2} \mathrm{C}(\mathrm{O}) \mathrm{Cl}, \mathrm{Et}{ }_{3} \mathrm{~N}, \mathrm{DMAP}, \mathrm{THF} / \mathrm{to}-$ luene, 15 min, $60 \%$. vi. HFxpyridine, THF, RT, 26 h, 90\%.

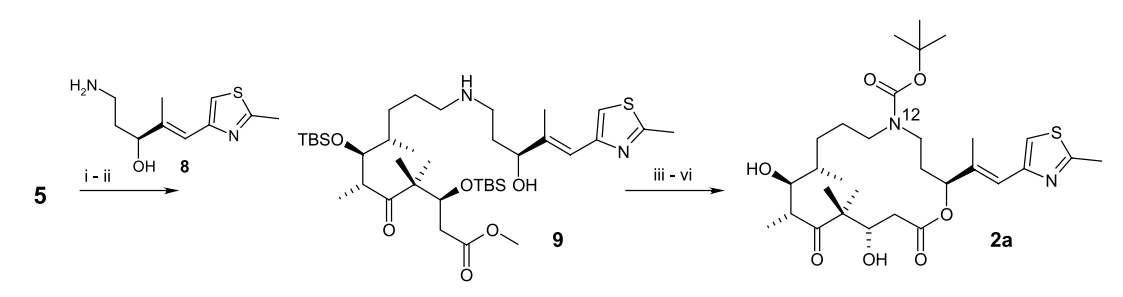

Scheme 3. i. Mes-Cl, $\mathrm{Et}_{3} \mathrm{~N}, \mathrm{CH}_{2} \mathrm{Cl}_{2}, 0^{\circ} \mathrm{C}, 1 \mathrm{~h}, 91 \%$. ii. 8, $\mathrm{MeOH}, 70{ }^{\circ} \mathrm{C}, 24 \mathrm{~h}, 30 \%$. iii. $\mathrm{BOC}_{2} \mathrm{O}, \mathrm{Et}_{3} \mathrm{~N}$, $\mathrm{CH}_{2} \mathrm{Cl}_{2}, \mathrm{RT}, 2 \mathrm{~h}, 49 \%$. iv. $\mathrm{LiOH}$ (6 equiv.), i- $\mathrm{PrOH} / \mathrm{H}_{2} \mathrm{O} 4: 1,55^{\circ} \mathrm{C}$, 16 h, $83 \%$. v. a. $2,4,6-\mathrm{Cl}_{3} \mathrm{C}_{6} \mathrm{H}_{2} \mathrm{C}(\mathrm{O}) \mathrm{Cl}$, $\mathrm{Et}_{3} \mathrm{~N}$, THF, $0{ }^{\circ} \mathrm{C}, 15 \mathrm{~min}$; b. dilute with toluene, add to solution of DMAP in toluene, $75{ }^{\circ} \mathrm{C}, 3 \mathrm{~h}, 90 \%$. vi. HFxpyridine, THF, RT, 17 h, 22\%.

Table 2. Induction of tubulin polymerization and growth inhibition of human carcinoma cell lines by 12-aza-epothilones 2

$\begin{array}{ccccc}\text { Compound } & \mathrm{R} & \begin{array}{c}\text { \% Tubulin } \\ \text { Polymerizationa }\end{array} & \begin{array}{c}\mathrm{IC}_{50} \mathrm{~KB}-31 \\ {[\mathrm{nM}]^{\mathrm{b}}}\end{array} & \begin{array}{c}\mathrm{IC}_{50} \mathrm{~KB}-8511 \\ {[\mathrm{nM}]^{\mathrm{b}}}\end{array} \\ \mathbf{2 a} & \mathrm{O}-\text { tert. }-\mathrm{C}_{4} \mathrm{H}_{9} & 27 & 31 & 105 \\ \mathbf{2 b} & \mathrm{OCH}_{2} \mathrm{Ph} & <10 & 297 & 703 \\ \mathbf{2 c} & \mathrm{OC}_{2} \mathrm{H}_{5} & 17 & 85 & 465 \\ \mathbf{2 d} & \mathrm{O}-\mathrm{iso}_{5}-\mathrm{C}_{4} \mathrm{H}_{9} & <10 & 297 & 737 \\ \mathbf{2 e} & \mathrm{CH}_{3} & <10 & 116 & \mathrm{ND}^{\mathrm{c}} \\ \mathbf{2 f} & \mathrm{C}_{2} \mathrm{H}_{5} & <10 & 71 & 1352 \\ \mathbf{2 g} & \text { tert. }-\mathrm{C}_{4} \mathrm{H}_{9} & <10 & 206 & >1000 \\ \mathbf{2 h} & \mathrm{C}_{6} \mathrm{H}_{5} & <10 & >1000 & >1000\end{array}$

alnduction of polymerization of porcine brain microtubule protein by $5 \mu \mathrm{M}$ of test compound relative to the effect of $25 \mu \mathrm{M}$ of Epo B, which gave maximal polymerization ( $85 \%$ of protein input). ${ }^{\text {b }} \mathrm{C}_{50}{ }^{-}$ values for growth inhibition of human epidermoid carcinoma cell lines KB-31 and KB-8511. Values generally represent the average of two independent experiments. ${ }^{C}$ Not determined. sons for the lack of biological activity of $\mathbf{1 a}$ and related analogs have not been elucidated, but subsequent data obtained for other (non amide-based) structures suggested that increasing the steric bulk at $\mathrm{C}(13)$ was generally associated with a significant decrease in potency. In light of these findings, we decided to continue exploration of the potential utility of nitrogen incorporation at position 12 of the macrocycle as a functional handle for further substitution without concomitant modification of C(13). At the most straightforward level this approach involved simple acylation of the 12-nitrogen atom, thus leading to amideand carbamate-based analogs of type 2 (Scheme 1), whose carbonyl oxygen could potentially assume the role of the epoxide oxygen in natural epothilones. The synthesis of these analogs is exemplified in Scheme 3 for a compound incorporating a BOC-protecting group on N(12) (2a). Removal of the BOC-group from $\mathbf{2 a}$ gave the free amine, which was converted to a series of other analogs $\mathbf{2 b}-\mathbf{2 h}$ (Table 2) by acylation with the respective acid chlorides or chloroformates.

These compounds were tested for their ability to promote the polymerization of tubulin in vitro, a parameter which is frequently used as an indirect measure for the microtubule-stabilizing potency of microtubule-stabilizing agents (vide supra). At the same time the antiproliferative activity of compounds $\mathbf{2} \mathbf{a}-\mathbf{2} \mathbf{h}$ was assessed against the human epidermoid cancer cell lines KB-31 and KB-8511 (Table 2), which serve as representative examples of drug sensitive and phosphoglycoprotein-170 (P-gp) overexpressing, multidrug-resistant human cancer cell lines, respectively (e.g. [13][14]).

As illustrated by the data summarized in Table 2, compounds of type 2 , although less active inhibitors of cancer cell growth than Epo A or B, can indeed be potent antiproliferative agents. Interestingly, however, some of these analogs are significantly less active against the multidrug-resistant KB8511 line than the drug-sensitive KB-31 parental line, thus indicating that compounds $\mathbf{2}$ are better P-gp substrates than natural epothilones. The structural basis for this phenomenon is not understood at this point, but the finding is in line with a more general tendency for polar epothilone analogs (e.g. compounds incorporating amide bonds or additional hydroxyl groups) to exhibit increased resistance factors in the KB-31/KB-8511 cell line pair (i.e. increased ratios of $\mathrm{IC}_{50}$ (KB8511)/IC ${ }_{50}$ (KB-31); M. Wartmann, K.-H. Altmann, unpublished observations). The most interesting of the compounds included in Table 2 is analog $\mathbf{2 a}$, which is only $c a$. 15 -fold less active against the drug-sensitive KB-31 line than Epo A (and thus roughly equipotent with Epo C) and is character- 
ized by an only modest resistance factor of $\sim 3$. This analog also shows measurable induction of tubulin polymerization in vitro, but it remains to be determined whether the antiproliferative activity of $\mathbf{2 a}$ is mainly related to interference with microtubule functionality or whether other/additional mechanisms may also be operative.

\subsection{Conformationally Constrained Analogs}

A significant part of our analog program was directed at side-chain modified analogs of epothilones. Apart from more conventional structures incorporating an olefinic double bond as a linker between the macrolactone ring and different types of heterocycles [31], we have also studied a more significantly modified family of analogs, which are characterized by the rigidization of the heterocycle-bearing side-chain (Fig. 2) [32]. The design of these compounds was guided by preliminary NMR data on the bioactive (tubulin-bound) conformation of Epo A, which indicated that the $\mathrm{C}(16) / \mathrm{C}(17)$ double bond and the aromatic $\mathrm{C}(18)-\mathrm{N}$ bond were present in a transoid arrangement (corresponding to $\mathrm{a} \sim 180^{\circ} \mathrm{C}(16)-\mathrm{C}(17)-\mathrm{C}(18)$ $\mathrm{N}(22)$ torsion angle). (These data have subsequently been consolidated and have recently appeared in the literature [33]).

The synthesis of this new type of sidechain modified Epo B and D analogs is exemplified in Scheme 4 for the quinolinebased structure $\mathbf{4 b}$.

Key steps in the construction of this molecule includes (i) the $\mathrm{Pd}(0)$-catalyzed Suzuki-type coupling between $\mathbf{1 0}$ and olefin 5 to establish the $\mathrm{C}(11) / \mathrm{C}(12)$ bond in $60 \%$ yield, (ii) Yamaguchi-type macrolactonization of the seco-acid derived from 11 by ester saponification and selective removal of the $\mathrm{C}(15)$-OTBS-protecting group, and (iii) epoxidation of deoxy-4b (Fig. 2) with $\mathrm{MeReO}_{3}$. Epoxidation proceeded with $c a$. 6:1 selectivity, but was slightly complicated by the fact that $\mathrm{N}$-oxidation of the quinoline nucleus proceeded faster than epoxidation of the double bond. However, this problem was readily overcome through deliberate double oxidation of deoxy-4b and subsequent selective reduction of the N-oxide by means of $\mathrm{Ra}-\mathrm{Ni}$ to provide the desired Epo $\mathrm{B}$ analog $\mathbf{4 b}$ in a (non-optimized) $37 \%$ yield for the two-step sequence from deoxy-4b [32].

Epothilone analogs $\mathbf{4 a} /$ deoxy-4a, 4b/deoxy-4b, and 4c/deoxy-4c are generally more potent inhibitors of human cancer cell proliferation than the respective parent compounds Epo B/Epo D (Table 3). The activity increase is more pronounced for analogs of the deoxy-type, which can be $>10$-fold more potent antiproliferative agents than Epo D (deoxy-4c); in addition, these compounds are clearly more potent than (epoxide-based) Epo A.

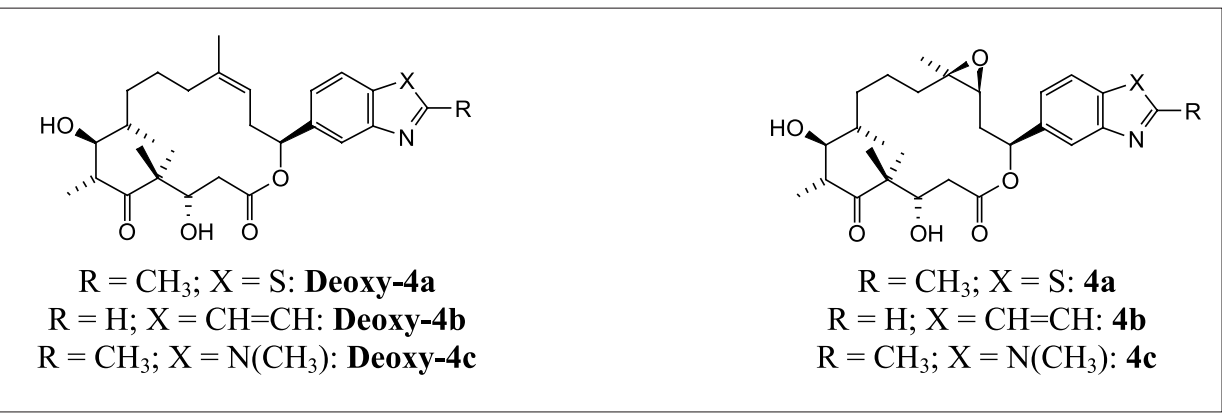

Fig. 2. Conformationally constrained side-chain modified analogs of epothilones

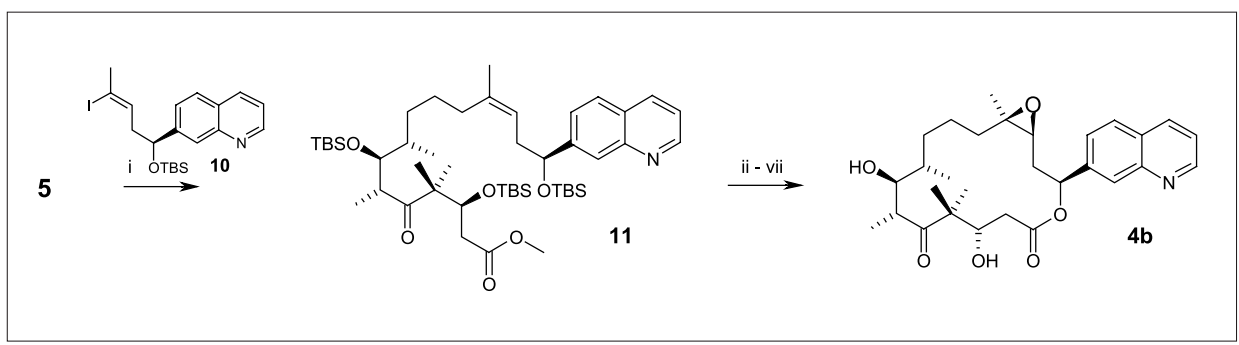

Scheme 4. i. a. Olefin 5 (1.25 equiv), 9-BBN, THF, RT, 4 h; b. add to mixture of $\mathrm{Cs}_{2} \mathrm{CO}_{3}$ (1.5 equiv.), $\mathrm{PdCl}_{2}$ (dppf) 2 (0.1 equiv.), $\mathrm{Ph}_{3} \mathrm{As}$ (0.2 equiv.), vinyl iodide 10 (1 equiv.), DMF, $-10{ }^{\circ} \mathrm{C} \rightarrow \mathrm{RT}, 16 \mathrm{~h}, 90 \%$. ii. $\mathrm{LiOH}$ (6 equiv.), i- $\mathrm{PrOH} / \mathrm{H}_{2} \mathrm{O} 4: 1,50{ }^{\circ} \mathrm{C}, 7 \mathrm{~h}, 84 \%$. iii. TBAF (3 equiv.), THF, RT, $18 \mathrm{~h}, 84 \%$. iv. a. $2,4,6-\mathrm{Cl}_{3} \mathrm{C}_{6} \mathrm{H}_{2} \mathrm{C}(\mathrm{O}) \mathrm{Cl}, \mathrm{Et}_{3} \mathrm{~N}, \mathrm{THF}, 0^{\circ}, 15 \mathrm{~min} ; \mathrm{b}$. dilute with toluene, add to solution of DMAP in toluene, $75^{\circ} \mathrm{C}, 3 \mathrm{~h}, 70 \%$. v. HFxpyridine, THF, RT, 17 h, 73\%. vi. $\mathrm{MeReO}_{3}, \mathrm{H}_{2} \mathrm{O}_{2}$, pyridine, $\mathrm{CH}_{2} \mathrm{Cl}_{2}, \mathrm{RT}, 17 \mathrm{~h}$. vii. $\mathrm{H}_{2}$, Ra-Ni, EtOH, RT, 37\% (2 steps).

Table 3. Growth inhibition of the human epidermoid cancer cell lines KB-31 and KB-8511 by sidechain modified epothilone analogs 4 and deoxy-4. , $^{\text {,b }}$

\begin{tabular}{cccccc} 
Compound & \multicolumn{2}{c}{ Cell line } & Compound & \multicolumn{2}{c}{ Cell line } \\
& KB-31 & KB-8511 & & KB-31 & KB-8511 \\
Epo D & 2.70 & 1.44 & Epo B & 0.19 & 0.18 \\
Deoxy-4a & 0.45 & 0.23 & $4 a$ & 0.13 & 0.09 \\
Deoxy-4b & 0.59 & 0.38 & $\mathbf{4 b}$ & 0.11 & 0.10 \\
Deoxy-4c & 0.21 & 0.73 & $\mathbf{4 c}$ & 0.14 & 0.38
\end{tabular}

aFor structures see Fig. 2. b $_{50}$-values for growth inhibition of human epidermoid carcinoma cell lines KB-31 and KB-8511. Values represent means of at least three independent experiments. (Data from [32]).

This is an intriguing finding, as only few other modifications have been described in the literature, which lead to analogs with enhanced in vitro activity over natural epothilones (for a recent example [34]). Interestingly, however, the observed increase in antiproliferative activity does not seem to be a consequence of more effective interactions with tubulin (data not shown), but may rather be related to parameters such as cell penetration or intracellular accumulation. Given the fact that Epo D is currently undergoing phase II clinical trials, the improved antiproliferative activity of analogs deoxy-4a, $\mathbf{- 4 b}$, and $\mathbf{- 4 c}$ could make these compounds interesting candidates for further development.

\section{Conclusions}

Examples described in this paper demonstrate that epothilone analogs with significant alterations to the natural structural scaffold can still retain profound biological activity in vitro. Future work will focus on the in vivo evaluation of selected compounds as well as the design of simplified analogs incorporating even more radical deviations from the lead structures Epo $\mathrm{A}$ and $\mathrm{B}$. The overall pharmacological profile of such compounds may be distinctly different from that of the natural products or closely related analogs and ideally these changes would translate into improved therapeutic utility (i.e. a broader therapeu- 
tic window). Whether or not this will be true, and if so, for which cases, can only be determined experimentally and ultimately will require the clinical evaluation of such compounds in humans.

\section{Acknowledgements}

All the work described in this paper was conducted at the Novartis Institute for Biomedical Research in Basel while KHA was still an employee of Novartis Pharma AG (until June 30, 2002). KHA is grateful to the company for the opportunity to conduct this research and to many colleagues for their collaboration and advice. With regard to the specific results described the authors are indebted to K. Hauenstein, T. Hatzinger, J. Köppler, M. Lartigot, K. Nathan, J. Loretan, R. Reuter, W. Vetterli, R. Vogelsanger, and S. Wojeik for their excellent technical assistance.

Received: July 28, 2004

[1] For the most prominent successful example in this area, cf. e.g. R. Capdeville, E. Buchdunger, J. Zimmermann, A. Matter, Nature Reviews Drug Discovery 2002, 1, 493-502.

[2] M.C. Lu, in 'Cancer Chemotherapeutic Agents', Ed. W.O. Foye, Washington, DC, American Chemical Society 1995, 345-368.

[3] cf. e.g. a) T.M. Mekhail, M. Markman, Exp. Opin Pharmacother. 2002, 3, 755-766; b) C. Obasaju, G.R. Hudes, Hematology/Oncology Clinics of North America 2001, 15, 525-545.

[4] E. Hamel, Med. Res. Rev. 1996, 16, 207-231.

[5] E.K. Rowinsky, Ann. Rev. Med. 1997, 48, 353-374.

[6] P.B. Schiff, J. Fant, S.B. Horwitz, Nature 1997, 277, 665-667.

[7] a) G. Höfle, N. Bedorf, K. Gerth, H. Reichenbach, German patent disclosure DE 4138042, May 5, 1993 (Priority Nov. 19, 1991). b) K. Gerth, N. Bedorf, G. Höfle,
H. Irschik, H. Reichenbach, J. Antibiotics 1996, 49, 560-564.

[8] D.M. Bollag, P.A. McQueney, J. Zhu, O. Hensens, L. Koupal, J. Liesch, M. Goetz, E. Lazarides, C.A. Woods, Cancer Res. 1995, 55, 2325-2333.

[9] K.-H. Altmann, Curr. Opin. Chem. Biol. 2001, 5, 424-431.

[10] H. Prinz, Exp. Rev. Anticancer Ther. 2002, 2, 695-708.

[11] M.A. Jordan, Curr. Med. Chem.: AntiCancer Agents 2002, 2, 1-14.

[12] R.J. Kowalski, P. Giannakakou, E. Hamel, J. Biol. Chem. 1997, 272, 2534-2541.

[13] K.-H. Altmann, M. Wartmann, T. O'Reilly, Biochim. Biophys. Acta 2000, 1470 , M79-M91.

[14] M. Wartmann, K.-H. Altmann, Curr. Med. Chem.: Anti-Cancer Agents 2002, 2, 123-148.

[15] P. Giannakakou, D. L. Sackett, Y. K. Kang, Z. Zhan, J.T. Buters, T. Fojo, M.S. Poruchynsky, J. Biol. Chem. 1997, 272, 17118-17125.

[16] K.-H. Altmann, Mini-Rev. Med. Chem. 2003, 3, 149-158.

[17] K.-H. Altmann, Curr. Pharm. Des., in press.

[18] R.M. Borzilleri, G.D. Vite, Drugs of the Future 2003, 27, 1149-1163.

[19] G. Höfle, N. Bedorf, H. Steinmetz, D. Schomberg, K. Gerth, H. Reichenbach, Angew. Chem. Int. Ed. Engl. 1996, 35, 1567-1569.

[20] K.C. Nicolaou, F. Roschangar, D. Vourloumis, Angew. Chem. Int. Ed. 1998, 37, 2014-2045.

[21] C.R. Harris, S.J. Danishefsky, J. Org. Chem. 1999, 64, 8434-8456.

[22] K.C. Nicolaou, A. Ritzen, K. Namoto, JCS Chem. Commun. 2001, 1523-1535.

[23] K.-H. Altmann, Org. Biomol. Chem. 2004, 2, 2137-2152.

[24] M.D. Chappell, S.J. Stachel, C.B. Lee, S.J. Danishefsky, Org. Lett. 2000, 2, 1633-1636.

[25] D. Meng, D.S. Su, A. Balog, P. Bertinato, E.J. Sorensen, S.J. Danishefsky, Y.H. Zheng, T.C. Chou, L. He, S.B. Horwitz, J. Am. Chem. Soc. 1997, 119, 2733-2734.
[26] D.S. Su, A. Balog, D. Meng, P. Bertinato, S.J. Danishefsky, Y.H. Zheng, T.C. Chou, L. He, S.B. Horwitz, Angew. Chem. Int. Ed. Engl. 1997, 36, 2093-2096.

[27] K.C. Nicolaou, N. Winssinger, J. Pastor, S Ninkovic, F. Sarabia, Y. He, D. Vourloumis, Z. Yang, T. Li, P. Giannakakou, E. Hamel, Nature 1997, 387, 268-272.

[28] K.C. Nicolaou, D. Vourloumis, T. Li, J. Pastor, N. Winssinger, Y. He, S. Ninkovic, F. Sarabia, H. Vallberg, F. Roschangar, N.P. King, M.R.V. Finlay, P. Giannakakou, P. Verdier-Pinard, E. Hamel, Angew. Chem. Int. Ed. Engl. 1997, 36, 2097-2103.

[29] K.-H. Altmann, G. Bold, G. Caravatti, D. Denni, A. Flörsheimer, A. Schmidt, G. Rihs, M. Wartmann, Helv. Chim. Acta 2002, 85, 4086-4110.

[30] K.-H. Altmann, M.J.J. Blommers, G. Caravatti, A. Flörsheimer, K.C. Nicolaou, T. O'Reilly, A. Schmidt, D. Schinzer, M. Wartmann, in 'Anticancer Agents Frontiers in Cancer Chemotherapy', Eds. I. Ojima, G.D. Vite, K.-H. Altmann, ACS Symposium Series 796. Washington DC, 2001, American Chemical Society, 2001, $112-130$.

[31] K.C. Nicolaou, R. Scarpelli, B. Bollbuck, B. Werschkun, M.M. Pereira, M. Wartmann, K.-H. Altmann, D. Zaharevitz, R. Gussio, P. Giannakakou, Chem. Biol. 2000, 7, 593-599.

[32] K.-H. Altmann, G. Bold, G. Caravatti, A. Flörsheimer, V. Guagnano, M. Wartmann, Bioorg. Med. Chem. Lett. 2000, 10, 2765-2768.

[33] T. Carlomagno, M.J.J. Blommers, J. Meiler, W. Jahnke, T. Schupp, F. Petersen, D. Schinzer, K.-H. Altmann, C. Griesinger, Angew. Chem. Int. Ed. 2003, 42, 2511-2515.

[34] A. Rivkin, F. Yoshimura, A.E. Gabarda, T.C. Chou, H. Dong, W.P. Tong, S.J. Danishefsky, J. Am. Chem. Soc. 2003, 125, 2899-2901. 